\title{
Feasibility of Using Volcanic Tuff Stone in Ground Heat Exchange for Cooling and Heating Systems in Buildings
}

\author{
Sameh Sqoor ${ }^{\mathrm{a}}$, Mohmd Sarireh ${ }^{\mathrm{b}}$, Ali Alahmer ${ }^{\mathrm{a}, *}$, Wafa Tarawneh $^{\mathrm{a}}$ \\ ${ }^{a}$ Department of Mechanical Engineering, Tafila Technical University, P. O. Box 179, 66110 Tafila, Jordan \\ ${ }^{b}$ Department of Civil Engineering, Tafila Technical University, P. O. Box 179, 66110 Tafila, Jordan
}

\begin{abstract}
Energy is a crucial sector in Jordan. In the world, Jordan is considered as the highest dependency on foreign energy sources, with $96 \%$ of the country's energy imported from oil and natural gas from neighboring countries. Numerically, it consumes $13 \%$ from the gross national product (GNP) costing 2.6 billion JD. The need is appearing to use new renewable resources specifically in air conditioning processes to reduce the bill of energy paid annually, in addition to the improve of practices and policies in energy sector. The current research focuses on the use of the ground heat exchange (GHE) model for cooling and heating system to improve the efficiency of the heating, ventilating, and air conditioning (HVAC) units in households and apartments using volcanic tuff stone. A GHE model was constructed by making a hole of $2 \mathrm{~m} \mathrm{X} 1.5 \mathrm{~m}$ with a depth of $1.5 \mathrm{~m}$, the volcanic tuff stone is placed enabling heat transfer through volume and voids of stone. The cooled air is extracted by a fan located at the exit (duct $20 \mathrm{X} 20 \mathrm{~cm}$ ) with electric capacity is 60 watts. The temperatures and relative humidity for air inlet and outlet were continuously measured during the period of testing. The results showed that the feasibility of using GHE model as a main part of heating/cooling system. The average temperature difference between the air inlet and exit of GHE model are $10^{\circ} \mathrm{C}$ and $3{ }^{\circ} \mathrm{C}$ for cooling and heating system respectively. Also, the relative humidity of air improves reasonably and increases in most cases.
\end{abstract}

Keywords: Ground heat exchange, energy, HVAC, volcanic tuff, cooling, heating.

\section{Introduction}

Jordan imports its need of energy (crude oil and gas) from neighboring countries. The national economy faces a difficulty due to energy issue because of the lack in conventional commercial energy resources. Even though, all parties interested in investing in renewable energy in Jordan, but their contribution in the energy consumption in Jordan is rather limited. In 1993, the share provided by solar water heaters was ranged from 1.7 to $1.8 \%$; photovoltaic systems provided $0.0016 \%$; hydro power provided $0.060 \%$; and wind power contribution of $0.007 \%$.Oil shale, did not contributed any power since its development is still at the planning stage. The energy consumption increased at average rate of $14 \%$ per year and the energy bill averaged about $13 \%$ of gross national product (GNP) and consumed most of the foreign exchange earned by exports of all Jordanian commodities in the last 3 decades [1].

Energy is considered to be one of the comprehensive development's tools and the main driver for all sectors, economic, social and service. So the exerted national efforts in the energy sector are focused to enable the Jordanian society to enjoy the services of energy in order to increase the level of welfare and improve life standards and to fight poverty. The investment in the energy sector is degrading and has high cost for Jordan, especially in conventional energy resources including

${ }^{*}$ Corresponding author. Tel.: +962 798277537,

E-mail: A.alahmer@ttu.edu.jo

(c) 2015 International Association for Sharing Knowledge and Sustainability

DOI: $10.5383 /$ ijtee.09.01.005 
crude oil importing, storing, and distributing products, also for natural gas, and oil shale. So, the investment in renewable energy and conservation of energy is a priority for the government of Jordan, and also for people in the country [2]. Table 1 represents the consumption of oil products in Jordan through the years 2007-2011 in thousands of tons. Even though there is a decrease in the consumption in some products, but the total sum of consumption explain an increase annually [2].

Table 2 represents the percentage of electric energy consumption in Jordan during the years 2007-2011 in 1000 tones. It is cleared that household sector has the maximum consumption among other sectors.
Table 1: The Consumptions of Oil Products (1000 tons) during 2007-2011 (MEMR Annual Report, 2011).

\begin{tabular}{c|cccccc}
\hline Year & $\begin{array}{c}\text { Liquefied } \\
\text { Gas }\end{array}$ & Gasoline & Kerosene & Diesel & Fuel Oil & Asphalt \\
\hline 2007 & 335 & 840 & 131 & 1799 & 1193 & 154 \\
2008 & 319 & 873 & 100 & 1493 & 1100 & 167 \\
2009 & 339 & 1022 & 111 & 1614 & 823 & 194 \\
2010 & 312 & 1065 & 69 & 1577 & 1381 & 152 \\
2011 & 378 & 1083 & 75 & 2407 & 1670 & 109 \\
Growth & & & & & & \\
$\begin{array}{c}\text { Rate } \\
(\%)\end{array}$ & 21 & 2 & 9 & 53 & 21 & -28 \\
\hline
\end{tabular}

Table 2: Sector Distribution for Consumption of Energy for the years 2007-2011 (MEMR Annual Report, 2011).

\begin{tabular}{c|cccccccc}
\hline Year & Household & Industry & Commercial & $\begin{array}{c}\text { Water } \\
\text { Pumping }\end{array}$ & $\begin{array}{c}\text { Street } \\
\text { Light }\end{array}$ & Others & $\begin{array}{c}\text { Total } \\
\text { Rate \% }\end{array}$ \\
\hline 2007 & 4001 & 2917 & 1759 & 1592 & 269 & - & 10538 & 10 \\
2008 & 4459 & 3128 & 1925 & 1713 & 284 & - & 11509 & 9.2 \\
2009 & 4926 & 2981 & 1978 & 1761 & 310 & - & 11956 & 3.9 \\
2010 & 5220 & 3258 & 2184 & 1867 & 315 & - & 12844 & 7.4 \\
2011 & 5441 & 3478 & 2260 & 1938 & 324 & 94 & 13535 & 5.4 \\
\hline
\end{tabular}

The generating of energy from renewable resources (wind, solar, and bio energy) is able to produce about $1,500 \mathrm{MW}$ initially, which can contribute to $10 \%$ of the energy consumption in Jordan. The following projects are considered the highest priorities for promoting sustainable energy production and consumption in Jordan: oil shale utilization, renewable energy, fossil fuel exploration, and geothermal plants. According to the (Geothermal Education Office, 2000) [3], a GWh can heat 860 thousand tons of water one degree centigrade (or bring about 9 million quarts of freezing water to a boil). GWh - gigawatt hour thermal can be defined as a unit of heat energy for non-electrical uses equal to 1000 megawatt hours (MWh). MW - megawatt electrical, a unit of electrical power equal to 1000 kilowatts $(\mathrm{kW})$ enough (in the U.S) for about 1000 people. Hepbasli and Ozgener [4] indicated that renewable energy is the key source of energy for Turkey and the whole world in future because of natural resource depletion. GE is used for electric power generation and direct utilization in Turkey, which is among the first five countries in the world in geothermal direct use applications. Direct use of geothermal resources has expanded rapidly last 36 years from space heating of single buildings to district heating, greenhouse heating, industrial usage, modern balneology and physical treatment facilities. GE is a relatively benign energy source, displaying fossil fuels and thus reducing greenhouse gas emissions. So, it is expected that GE development will significantly speed up in the country if the geothermal law becomes effective. Dickson and Fanelli [5] defined the geothermal heat which is contained or obtained from earth as geothermal energy. Human ancestors found through their observations for volcanoes and hot springs the geothermal or earth energy. The first measurements by thermometer were probably performed in 1740 , in a mine near Belfort, in France (Bullard, 1965). By 1870 modern scientific methods were being used to study the thermal regime of the Earth, but it was not until the twentieth century, and the discovery of the role played by radiogenic heat, that we could fully comprehend such phenomena as heat balance and the Earth's thermal history. Estimates from more than twenty years ago gave the total heat content of the Earth, reckoned above an assumed average surface temperature of $15{ }^{\circ} \mathrm{C}$, in the order of $12.6 \times 1024 \mathrm{MJ}$, and that of the crust in the order of 5.4 x $1021 \mathrm{MJ}$. The thermal energy of the Earth is therefore immense, but only a fraction can be utilized by man. Geothermal energy temperature increase with depth at an average rate of $2.5-3^{\circ} \mathrm{C} / 100 \mathrm{~m}$. The limitation on geothermal resources in utilization is the availability of hot water or steam carrier that will rise from the resource to the earth surface for human use. Muffler and Cataldi [6] defined the geothermal resource base as all the thermal energy in the earth's crust under a given area, measured from mean annual temperature. The shallow part of the energy resource base that can be produced by drilling is called the accessible resource base, which could be partially useful and economic. This is highly affected by vertical and horizontal directions in the earth surface. The volume method is the most useful among surface thermal flux, planar fracture and magmatic heat budget because (1) it is applicable to virtually any geologic environment, (2) the required parameters can in principle be measured or estimated, (3) the inevitable errors are in part compensated and (4) the major uncertainties (recoverability and resupply) are amenable to resolution in the foreseeable future. The weakness in geothermal extraction methods is how much of the accessible resource base can be extracted in future at specific time. 
Omer [7] indicated the ground source heat pump was increasingly used for building cooling and heating with the average annual rate of increase of $10 \%$ in recent years. A numerical model for ground heat exchanger was developed by Badescu [8]. This model has the ability to evaluate the ground temperature profile at various depths of ground. Also the potential for using ground heat exchanger for under real climatic conditions was investigated. Fan et al. [9] developed a mathematical model for a vertical ground heat exchanger by taking the impact the impact of coupled heat conduction and groundwater advection on the heat transfer between the GHE and its surrounding soil. AlDabbas [10] showed that for domestic buildings, the using of ground heat exchanger in Ma'an /Jordan will save $70 \%$ in the heating mode and up to $50 \%$ in the cooling mode compared to conventional fossil fuel systems.

The idea in the current research is to use the effective surrounding material in terms of volcano tuff stone for modeling the ground heat exchange for air conditioning processes. The earth maintains a constant temperature at a specific depth $(3 \mathrm{~m})$ during summer and winter. So, circulation of air through the yard ground of a house will give extra heat or cooling for this air in winter or summer. The heated or cooled air can be used directly in HVAC units in winter or summer reducing the consumption rate and cost. Even the heat exchange cycle goes in-door or out-door, ground heat exchanger can help in increasing the efficiency of the HVAC system.

The structure of this manuscript starts by discussing the geothermal definitions, its advantages and related researches in section one, while section two displays a methodology and experimental setup. Section three presents a brief details about tuff volcanic stone. The data research and results were discussed in section four. Finally section five summarizes the study findings through the conclusion.

\section{Methodology of GHE Design}

The ground heat exchanger consists of sing horizontal loop filled with volcanic tuff rocks which are placed in a certain way and include gaps between them for heat exchange. The dimensions of this loop or hole as $2 \mathrm{~m}$ long, $1.5 \mathrm{~m}$ wide and $1.5 \mathrm{~m}$ deep. The ambient air is extracted by a fan located at the exit square duct $(20 * 20$ $\mathrm{cm})$, capacity of a fan equal 60 watts. During the experiment, the temperatures and relative humidity for air inlet and outlet were continuously measured using a digital Hygro-thermometer (commercial name LAM880D). When air passes through the loop, air affected by geothermal energy so in the summer the system will disperse heat but in winter it will absorb. Figure 1 illustrates the GHEs for cooling and heating model. Figure 2 displays the application of GHEs principle in winter and in summer. Modeling the ground heat exchanger using volcanic tuff stones is depicted in Figure 3.

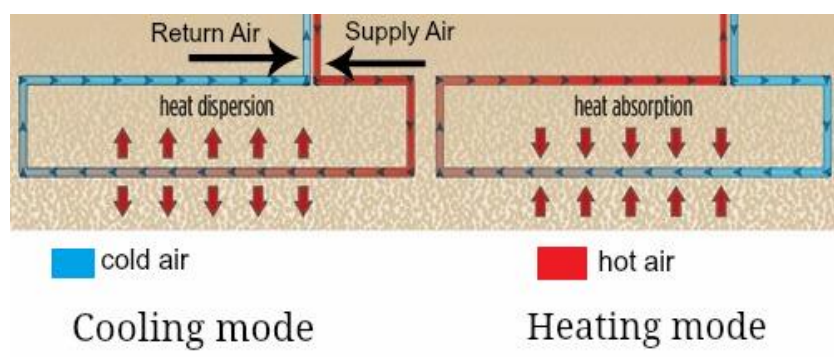

Figure 1: Ground heat exchanger for cooling and heating processes.

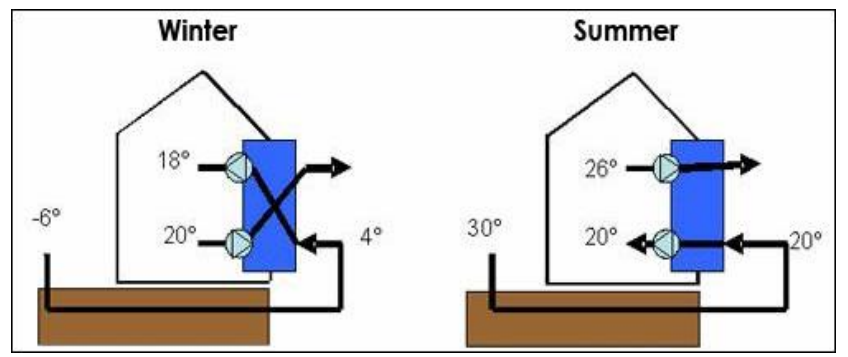

Figure 2: Application of GHEs in winter and in summer.

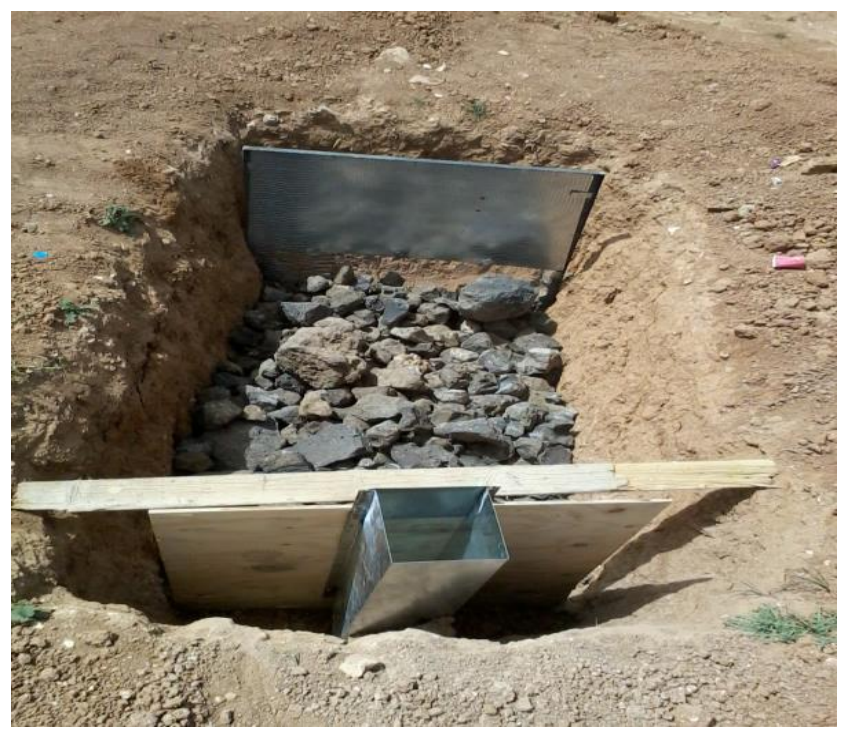

Figure 3: Modeling the ground heat exchanger using volcanic tuff stones.

\section{Volcanic Tuff Stone}

Volcanic tuff stone is formed from volcanoes after exposure to weathering. Volcanic tuff has high technical specifications in terms of porosity ranging from $29-75 \%$ and a little volumetric weight. According to chemical construction, there are two types: (1) Acidic Tuff: It has to a high percentage of silica up to about $66 \%$ and at the same time it contains the ratios expensive than aluminum, potassium, sodium, while the rates of calcium, magnesium, iron low; For this reason, so it contain high rates of metals light color; the next type (2) Basic Tuff: This type contains less silica rates up to about $45 \%$ and this quality are rich in mineral dark color to high rates of calcium, magnesium and iron. 
The grain size; where volcanic tuff is divided depending on the size of the grains into the following types: (i) Volcanic stones: This stones have medium to soft grains size ranging from $4-32 \mathrm{~mm}$, consisting of solid debris materials take different shapes and sizes and are located in different colors including red, gray, yellow and black, where black is the best due to its distinctive hydraulic properties. (ii) Volcanic ash and dust: Consist with small grains up to the size of floating dust is formed after deposition in areas far from volcanoes tuff soft component, one of the best quality types of tuff ranges in volume grains between $(0.01-4 \mathrm{~mm})$.

\section{Research Data and Results}

After building the model in Tafila city, Jordan. The temperature and relative humidity of air entering air and leaving from the model were recoded. The difference in temperature between the entering and out air is the first evidence for potential using the GHE model in cooling and heating of air. Table 3 presents the temperatures in and out through the circulation of air into the GHE system model for different days. Table 4 displays the difference between air temperatures before and after using the GHE model. The negative difference in temperatures were collected in 20th of April, 2014 means air entering temperature is less than of air out temperature, so air get wormed by circulation through the GHE model. These readings were taken afternoon, the weather become slightly cold. It uses the earth as a heat source (in the winter) or a heat sink (in the summer).

Table 3: Temperature of in and out air of the GHE model.

\begin{tabular}{|c|c|c|c|c|c|c|c|c|c|c|c|c|c|}
\hline \multicolumn{10}{|c|}{ Temperature $\left({ }^{\circ} \mathrm{C}\right)$ of entering air and out air Using The GHE Designed Model 2013} \\
\hline \multirow{2}{*}{ Time } & \multicolumn{1}{|c|}{18 April } & \multicolumn{1}{|c|}{19 April } & \multicolumn{2}{|c|}{20 April } & \multicolumn{2}{|c|}{29 April } & \multicolumn{2}{|c|}{30 April } & \multicolumn{2}{|c|}{1 May } \\
\cline { 2 - 14 } & $\mathrm{T}_{\text {in }}$ & $\mathrm{T}_{\text {out }}$ & $\mathrm{T}_{\text {in }}$ & $\mathrm{T}_{\text {out }}$ & $\mathrm{T}_{\text {in }}$ & $\mathrm{T}_{\text {out }}$ & $\mathrm{T}_{\text {in }}$ & $\mathrm{T}_{\text {out }}$ & $\mathrm{T}_{\text {in }}$ & $\mathrm{T}_{\text {out }}$ & $\mathrm{T}_{\text {in }}$ & $\mathrm{T}_{\text {out }}$ \\
\hline $11: 00$ & 27.6 & 19.3 & 19.0 & 16.0 & - & - & - & - & 27.4 & 20.0 & 29.0 & 20.5 \\
\hline $11: 30$ & 28.0 & 18.9 & 18.0 & 15.0 & - & - & - & - & 27.6 & 18.0 & 30.0 & 21.0 \\
\hline $12: 00$ & 28.3 & 18.1 & 17.0 & 16.2 & - & - & 29.3 & 20.4 & 28.2 & 19.3 & 28.0 & 21.7 \\
\hline $12: 30$ & 29.5 & 18.2 & 17.5 & 15.0 & - & - & 29.4 & 18.4 & 29.0 & 20.2 & 29.0 & 20.5 \\
\hline $13: 00$ & 29.0 & 18.4 & 17.0 & 14.3 & 12.2 & 14.9 & 29.1 & 18.1 & 27.1 & 21.1 & 29.0 & 21.2 \\
\hline $14: 00$ & 27.7 & 17.0 & 19.0 & 14.3 & 13.0 & 15.1 & 29.1 & 17.6 & 28.3 & 20.1 & 28.0 & 22.4 \\
\hline $14: 30$ & 26.8 & 17.1 & 18.3 & 15.3 & 12.3 & 14.8 & 29.4 & 18.0 & 27.0 & 19.3 & 29.5 & 22.1 \\
\hline $15: 00$ & 27.8 & 19.7 & 17.0 & 14.5 & 12.0 & 14.7 & 30.4 & 18.8 & 26.4 & 21.2 & 29.6 & 22.8 \\
\hline $15: 30$ & 27.6 & 19.3 & 16.8 & 14.6 & 10.0 & 14.1 & 27.9 & 17.3 & - & - & - & - \\
\hline $16: 00$ & 27.5 & 19.0 & 16.5 & 14.8 & 10.2 & 14.8 & - & - & 26.0 & 21.0 & - & - \\
\hline $16: 30$ & - & - & - & - & 10.5 & 15.1 & - & - & - & - & - & - \\
\hline Average & 27.98 & 18.5 & 17.61 & 15 & 11.46 & 14.79 & 28.95 & 18.45 & 27.44 & 20.02 & 29.54 & 26.28 \\
\hline
\end{tabular}

$\mathrm{T}_{\mathrm{in}}$ : Temperature of air entering the model, $\mathrm{T}_{\text {out }}$ : Temperature of air leaving the model

$\mathrm{T}_{\text {Difference }}\left({ }^{\circ} \mathrm{C}\right)$ : Difference in degree centigrade between air entering and leaving the model

Table 4: Air temperature difference in the GHE Model.

\begin{tabular}{|c|c|c|c|c|c|c|}
\hline \multicolumn{6}{|c|}{ Temperature Difference $\left({ }^{\circ} \mathrm{C}\right)$ Between entering air and out air Using The GHE Designed Model 2013} \\
\hline \multirow{2}{*}{ Time } & 18 April & 19 April & 20 April & 29 April & \multirow{2}{*}{30 April } & 1 May \\
\hline $11: 00$ & 8.3 & 3.0 & - & - & 7.4 & 8.5 \\
\hline $11: 30$ & 9.1 & 3.0 & - & - & 9.6 & 9.0 \\
\hline $12: 00$ & 10.2 & 2.1 & - & 8.9 & 8.9 & 6.3 \\
\hline $12: 30$ & 11.3 & 2.5 & - & 11.0 & 8.8 & 8.5 \\
\hline $13: 00$ & 10.6 & 1.9 & -2.7 & 11.0 & 6.0 & 7.8 \\
\hline $14: 00$ & 10.7 & 4.0 & -2.1 & 11.5 & 8.2 & 5.6 \\
\hline $14: 30$ & 9.7 & 3.0 & -2.5 & 11.4 & 7.7 & 7.4 \\
\hline $15: 00$ & 8.1 & 2.0 & -2.7 & 11.6 & 5.2 & 6.8 \\
\hline $15: 30$ & 8.3 & 2.5 & -4.1 & 10.6 & - & - \\
\hline $16: 00$ & 8.5 & 1.5 & -4.6 & - & 5.0 & - \\
\hline $16: 30$ & - & - & -4.6 & - & - & - \\
\hline Average & 9.48 & 2.55 & -3.33 & 10.5 & 7.42 & 7.49 \\
\hline
\end{tabular}


Figures 4 through 6 depict the graphical presentation for the temperature of air entering and leaving the GHE model. It can be seen clearly from Figure 4, the reduction in temperature almost constant and is nearly 8 ${ }^{\circ} \mathrm{C}$.

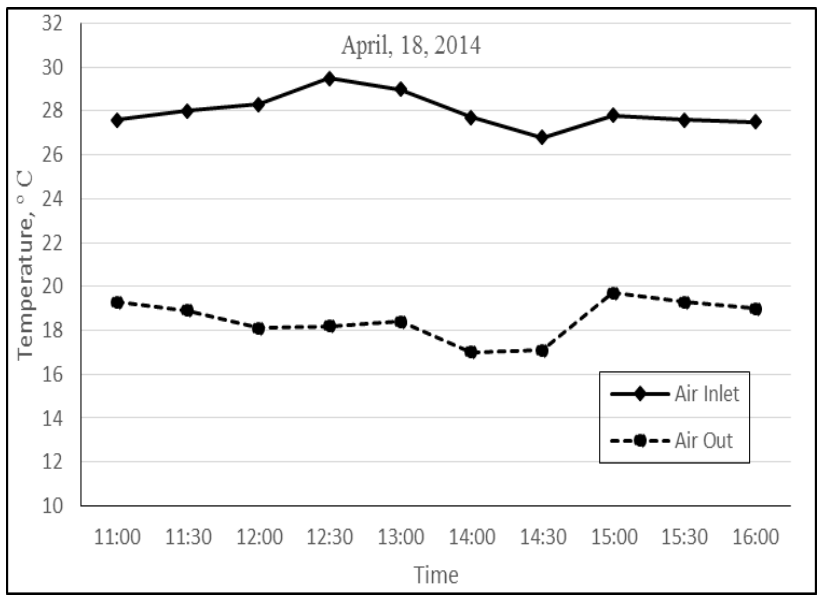

Figure 4: Temperature for in and out Air of GHE 18 April, 2013.

The next day (19 April, 2013) figure 5, the outside temperature dropped and it reached between 18 to $20^{\circ} \mathrm{C}$, so it had a lot of influence on the temperature at the output of generator. Also the variation of temperature at the outside of generator are more stable than the supply as illustrated in Figure 6.

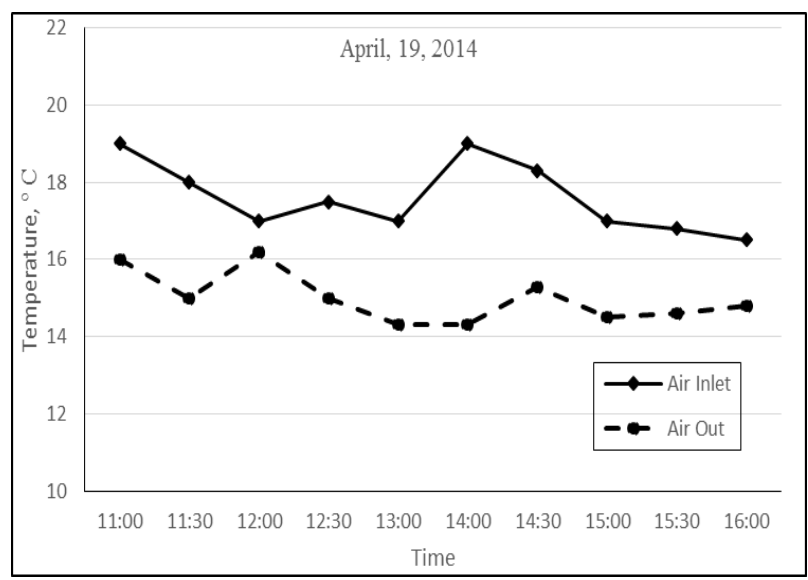

Figure 6 Temperature of entering and out Air of GHE on 19 April, 2013.

A day After ( 20 April), the atmospheric temperature radically decreases reached temperature between 10 to $12^{\circ} \mathrm{C}$, so the generator worked vice versa, for this reason the output temperature is raised, so in this place we can treat generator as a source of heat as illustrated in Figure 7.

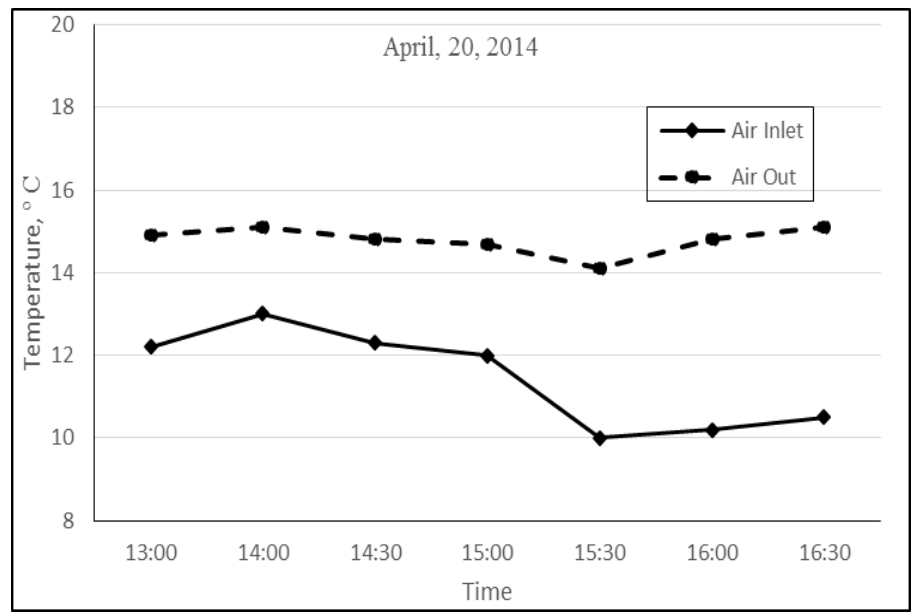

Figure 7 Temperature of entering and out Air of GHE on 20 April, 2013

Relive humidity is considered as an important input and output of the GHE operation. Table 5 presents relative humidity $\%$ of entering and leaving air in the GHE model.

Figure 8 through 10 present the relative humidity of the air entering the GHE model and that leaves the GHE model. From these figures clearly can be seen that the generator has a serious impact on the humidity, which improves air quality, more comfortable for people.

At the first day of the experiment (18 April) the relative humidity $(\mathrm{RH})$ of atmospheric air was low about $10 \%$ and when the air flow through the GHE the RH started to grow and it has acquired nearly $50 \%$ as illustrated in Figure 8.

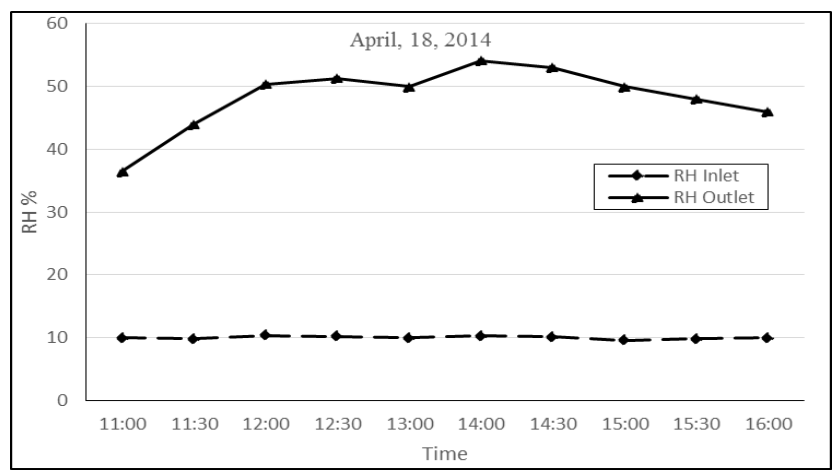

Figure 8 Relative Humidity for in and out Air on 18 April, 2013

In the next days of experiment, also influence could be seen GHE at RH, and independent on external conditions as illustrated in the Figures 9 and 10. 


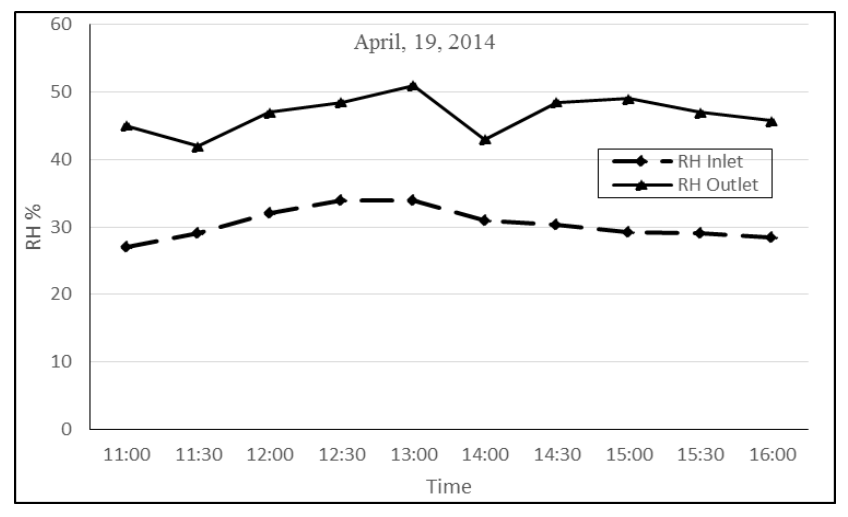

Figure 9 Relative Humidity for in and out for 19 April, 2013

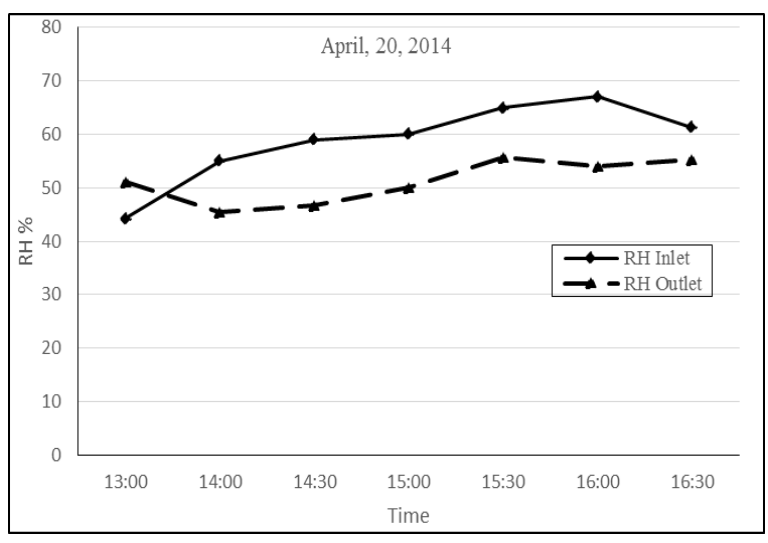

Figure 10 Relative Humidity for 20 April, 2013

Table 5 Relative Humidity of Air entering and Air Leaving The GHE Model

\begin{tabular}{|c|c|c|c|c|c|c|c|c|c|c|c|c|}
\hline \multicolumn{13}{|c|}{ Relative Humidity of entering air and out air Using The GHE Designed Model $2013\left({ }^{\circ} \mathrm{C}\right)$} \\
\hline \multirow[b]{2}{*}{ Time } & \multicolumn{2}{|c|}{18 April } & \multicolumn{2}{|c|}{19 April } & \multicolumn{2}{|c|}{20 April } & \multicolumn{2}{|c|}{29 April } & \multicolumn{2}{|c|}{30 April } & \multicolumn{2}{|c|}{1 May } \\
\hline & $\begin{array}{c}\mathrm{RH}_{\mathrm{i}} \\
\mathrm{n} \%\end{array}$ & $\begin{array}{c}\mathrm{RH}_{\text {out }} \\
\%\end{array}$ & $\begin{array}{c}\mathrm{RH}_{\mathrm{in}} \\
\%\end{array}$ & $\begin{array}{c}\mathrm{RH}_{\text {out }} \\
\%\end{array}$ & $\begin{array}{c}\mathrm{RH}_{\text {in }} \\
\%\end{array}$ & $\begin{array}{c}\mathrm{RH}_{\text {out }} \\
\%\end{array}$ & $\begin{array}{c}\mathrm{RH}_{\text {in }} \\
\%\end{array}$ & $\begin{array}{c}\mathrm{RH}_{\mathrm{ou}} \\
\mathrm{t} \%\end{array}$ & $\begin{array}{c}\mathrm{RH}_{\mathrm{in}} \\
\%\end{array}$ & $\begin{array}{c}\mathrm{RH}_{\mathrm{ou}} \\
{ }_{\mathrm{t}} \%\end{array}$ & $\begin{array}{c}\mathrm{RH}_{\text {in }} \\
\%\end{array}$ & $\begin{array}{c}\mathrm{RH}_{\text {out }} \\
\%\end{array}$ \\
\hline 11:00 & 10.0 & 36.5 & 27.0 & 45.0 & - & - & - & - & 11.1 & 30.0 & 11.0 & 36.5 \\
\hline $11: 30$ & 9.8 & 44.0 & 29.0 & 42.0 & - & - & - & - & 10.1 & 30.2 & 6.5 & 30.0 \\
\hline $12: 00$ & 10.4 & 50.4 & 32.0 & 47.0 & - & - & 5.3 & 25.0 & 9.8 & 29.1 & 9.3 & 21.5 \\
\hline $12: 30$ & 10.2 & 51.3 & 34.0 & 48.5 & - & - & 5.2 & 29.5 & 8.6 & 28.3 & 10.0 & 27.0 \\
\hline 13:00 & 10.0 & 50.0 & 34.0 & 51.0 & 44.2 & 51.0 & 5.2 & 30.0 & 9.1 & 28.1 & 12.0 & 26.0 \\
\hline $14: 00$ & 10.3 & 54.1 & 31.0 & 43.0 & 55.0 & 45.4 & 5.4 & 32.0 & 8.2 & 27.2 & 8.6 & 22.0 \\
\hline $14: 30$ & 10.1 & 53.0 & 30.4 & 48.5 & 59.0 & 46.7 & 5.6 & 26.0 & 7.3 & 27.9 & 10.3 & 25.0 \\
\hline $15: 00$ & 9.6 & 50.0 & 29.3 & 49.0 & 60.0 & 50.0 & 2.8 & 23.6 & 10.1 & 29.1 & 8.6 & 22.2 \\
\hline $15: 30$ & 9.8 & 48 & 29 & 47 & 65.0 & 55.7 & 3.5 & 28.3 & - & - & - & - \\
\hline $16: 00$ & 10.0 & 46.0 & 28.5 & 45.7 & 67.0 & 54.1 & - & - & 11.2 & 28.3 & - & - \\
\hline $16: 30$ & - & - & - & - & 61.3 & 55.2 & - & - & - & - & - & - \\
\hline Average & $\begin{array}{c}10.0 \\
4\end{array}$ & 48.37 & $\begin{array}{c}30.5 \\
8\end{array}$ & 46.63 & $\begin{array}{c}58.7 \\
9\end{array}$ & 51.16 & 4.5 & 23.4 & 9.5 & $\begin{array}{c}28.6 \\
9\end{array}$ & 9.54 & 26.28 \\
\hline
\end{tabular}

$\mathrm{RH}_{\mathrm{in}} \%$ : Relative humidity of air entering the GHE model, $\mathrm{RH}_{\mathrm{out}} \%$ : Relative humidity of air leaving the GHE model

\section{Conclusion}

The results which are taken from the records of the GHE model show a high feasibility and efficiency in using the model in cooling and heating. That for 18 of April, the results come to have the averages of $28.02^{\circ} \mathrm{C}$ for entering air and $18.14^{\circ} \mathrm{C}$ for leaving air of GHE model, with a difference in temperature of $9.61^{\circ} \mathrm{C}$. Other results confirm the feasibility in using GHE model application in cooling or heating in houses. Also, the results for the evening period are encouraging. The average temperature on 20 April, 2013 for entering air $11.46^{\circ} \mathrm{C}$, while the average temperature for leaving air is $14.79^{\circ} \mathrm{C}$, which can also give an evidence on using the GHE model for heating.

Another evidence on the feasibility for using the GHE model is the relative humidity of air that improves reasonably and increases in most cases. The difference in relative humidity between entering and leaving air comes in the average of about $38 \%, 16 \%, 8 \%, 19 \%$, 19\%, 17\% for 18 April, 19 April, 20 April, 29 April, 30 April, and 1May respectively. 


\section{Research Limitations}

The current research is very helpful and applicable for human use in cooling and heating of air before using directly in the HVAC. Although the current research gives clear evidences on the feasibility and applicability of the GHE model, but it has limitations in the need for working on the model in winter period as all the work had been conducted in summer period (April and May). Further data and work is needed in the future to complete data collection process on the designed model.

\section{References}

[1] F. Abdulla, M. Widyan, Z. Al-Ghazawi, S. Kiwan, H. Abu-Qdais, M. Hayajneh, A. Harb, M. Al-Nimr, Status of Jordan Renewable Energy Sector: Problems, Needs and Challenges, School of Engineering, Jordan University of Science and Technology: Jordan, 2011.

[2] Ministry of energy and mineral resources, Annual report, 2011, Available at: http://www.memr.gov.jo/LinkClick.aspx?fileticket= jtGDNwPrZRs\%3D\&tabid=243, Last cited December 6, 2014.

[3] Geothermal Education Office, 2000, Available at: http://geothermal.marin.org/geomap_1.html, Last cited December 6, 2014.
[4] A. Hepbasli, L. Ozgener, Development of geothermal energy utilization in Turkey: a review, Renewable and Sustainable Energy Reviews 8 (5) (2004): 433-460.

[5] Mary H. Dickson and Mario Fanelli. What is Geothermal Energy? Istituto di Geoscienze Georisorse, Pisa, Italy, Available at: http://www.metu.edu.tr/ mahmut/pete450/Dickson. pdf, Last cited December 6, 2014.

[6] P. Muffler, R. Cataldi, Methods for regional assessment of geothermal resources, Geothermics 7 (2) (1978): 53-89

[7] A. Omer, Ground-source heat pumps systems and applications, Renewable and Sustainable Energy Reviews 12 (2) (2008): 344-371.

[8] V. Badescu, Simple and accurate model for the ground heat exchanger of a passive house, Renewable energy 32 (5) (2007): 845-855.

[9] R. Fan, Y. Jiang, Y. Yao, Z. Ma, Theoretical study on the performance of an integrated ground-source heat pump system in a whole year, Energy 33 (11) (2008): 1671-1679.

[10] M. Al-Dabbas, Achievement of geothermal energy using ground heat exchanger in Ma'en. Journal of mechanical science and technology, 25(8) (2011): 2013-2023. 